\author{
Dorota Krystyna Rembiszewska* \\ Instytut Slawistyki Polskiej Akademii Nauk, Warszawa \\ https://orcid.org/0000-0003-0339-0879
}

\title{
Listy Zygmunta Glogera do Jana Karłowicza ze zbiorów Archiwum Historycznego w Wilnie
}

\author{
Letters from Zygmunt Gloger to Jan Karłowicz \\ from the collection of the Historical Archive in Vilnius
}

Abstract: The article contains the texts of 15 letters from 1877-1902, kept in the Historical Archive in Vilnius (Lietuvos vyriausiojo archyvaro tarnyba), in a set in the Vilnius Science Society. It is a correspondence of Zygmunt Gloger (1845-1919) - a folklore expert, archaeologist, cultural historian, author of Encyklopedia staropolska [Old Polish Encyclopaedia] - with Jan Karłowicz (1836-1903) - editor of the geographical and ethnographic monthly Wisła, and author of Stownik gwar polskich [Dictionary of the Polish Sub-Dialects]. These letters are accompanied by extensive comments, explaining the essence of the issues raised 
in the correspondence and familiarising the reader with the persons referred to.

Keywords: epistolography, archival legacy, collections of the Historical Archive in Vilnius, archaeology, cultural anthropology.

Przedstawiony zbiór listów Zygmunta Glogera (1845-1910) - archeologa, etnografa, krajoznawcy, historyka kultury do Jana Karłowicza (1836-1903) - redaktora miesięcznika geograficzno-krajoznawczego „Wisła”, autora Słownika gwar polskich, stanowi interesujące świadectwo spraw dotyczących wymienionego czasopisma i osób z nim związanych. Pokazuje wielką aktywność ziemianina z Jeżewa, różnorodność jego zainteresowań i pasji ${ }^{1}$.

Listy te są przechowywane w Archiwum Historycznym w Wilnie (Lietuvos valstybės istorijos archyvas), w zespole Wileńskiego Towarzystwa Naukowego, w tece Jana Karłowicza².

Pozostawiam niezmienioną pisownię, by dostarczyć badaczom języka tego okresu oryginalnego materiału. Zachowałam więc é pochylone, które jeszcze w tamtym czasie było dość konsekwentnie utrzymywane, na przykład: niemnowéj, odkrytéj, téj, Waszéj. Zgodnie z dawnym zwyczajem ortograficznym zapisuję grupę dwusylabową -yja, -ija w dopełniaczu liczby pojedynczej rzeczowników, a więc: melodyj, pozycyj, banifikacyj oraz podwojone litery w wyrazach obcego pochodzenia: professorów, Rossyi. Nie uwspółcześniłam zapisu nie z czasownikami - pozostawiłam pisownię łączną tam, gdzie podał autor: nieomieszkam, niepozwoliła. Wprowadziłam niezbędne poprawki interpunkcyjne, które ułatwią lekturę listów.

1 Zagadnienia omawiane w tej korespondencji przeanalizowano w artykule: D. K. Rembiszewska, Sprawy uczonego ziemianina - korespondencja Zygmunta Glogera z Janem Karłowiczem (w druku).

2 LVIA. 


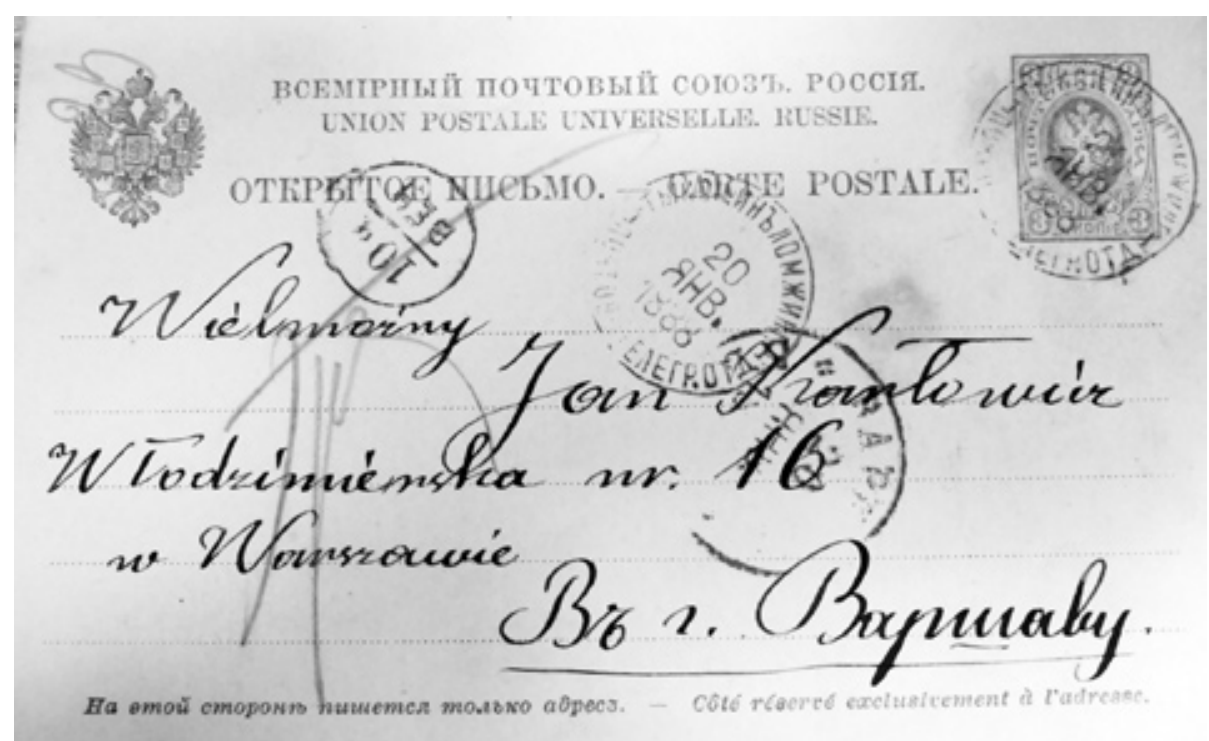

\section{Warszawa, d. 23 Lutego 1877 r. ${ }^{3}$}

Serdecznie przepraszam Szanownego Pana, że nie odpisałem natychmiast na list Jego z dnia 3-go Lutego, ale doszedł mię spóźniony, gdyż od dwóch miesięcy siedzę w Warszawie, gdzie jeszcze do końca Marca bawić będę. Przybyłem tu na dłużej, równie jak i w roku zeszłym dla pracy w tutejszych bibliotekach i archiwach.

Za przesyłkę, którą w całości odebrałem, serdecznie dziękuję - lubo przez księgarzy robię usilne starania, żeby dostać podobne spisy wiosek ze wszystkich naszych dziewięciu gubernij, bo do prac moich są bezwarunkowo potrzebne.

Zapytuje Szanowny Pan o drugą część Obchodów weselnych ${ }^{4}$ - rzecz tak się ma: Na druk pierwszej wydałem około rs. 500, z których wróciło mi się zaledwie kilkadziesiąt. A właśnie ten powrót kosztów przeznaczony był na

3 LVIA, k. 22-22v.

4 Pierwsza część - [Zygmunt Gloger], Obchody weselne przez Pruskiego z pięcioma drzeworytami w tekśsie z dwoma tablicami nut i mapka w końcu dzieła dołączona. Część pierwsza, Kraków 1869. Szerzej o tej publikacji: M. Piotrowska, Budowanie wspólnoty w przestrzeni społecznej. Kilka uwag na marginesie „Obchodów weselnych” Glogera, [w:] Zygmunt Gloger 1845-1910: pisarz, myśliciel, uczony. Rewizje, red. J. Leończuk, J. Ławski, Ł. Zabielski, Białystok 2016, s. 95-106. 
drukowanie części drugiej. Nie mogąc sam wydać, szukałem nakładcy, któremu oczywiście dawno pragnąłem pracę moją oddać, ale go nie znalazłem. Tak upływa już ósmy rok, a tymczasem część pierwsza została w połowie rozdana, w połowie po bankructwie księgarni krakowskiej Trzecieskiego ${ }^{5}$ poszła bez mojej wiedzy do antykwariuszów. $Z$ drugiej strony przybyło mi wiele materjałów do całości przedmiotu nowych poglądów, tak że dziś już możnaby tylko zrobić całkowite nowe wydanie i takowe niewątpliwie uskutecznię. Nie śpieszę się, bo materjały ciągle przybywają, a rzecz zyskuje przez to na wartości. To też spotkawszy w liście Szanownego Pana uprzejmą i zaszczytną dla mnie chęć udzielenia mi rzeczy ludowych z Jego zbiorów, polecam moje Obchody weselne Waszéj pamięci, a cokolwiek otrzymałbym kiedy, nieomieszkam robiąc użytek, źródło wyszczególnić!

Wycieczka na Wołyń powiodła mi się arcypomyślnie. Natrafiłem na okres wyłącznie kamienny w mogiłach i odkrytéj miejscowości zamieszkania ludzi tamtego czasu. Szkielety i części przedmiotów znalezionych przy nich, przesłałem z treściowym opisem do Krakowa, resztę zabrałem do Jeżewa ${ }^{6}$, bo mam pisać obszerniej o tych wykopaliskach. W pierwszym tomie rozpraw komisyi antropologicznéj będzie mój opis i studium Kopernickiego ${ }^{7}$ nad czaszkami. Wykopaliska moje uznano za najdawniejsze zabytki dotąd znalezione na ziemiach naszych w mogiłach.

Na rok 1879 zdecydowany jest kongres archeologiczny międzynarodowy w Krakowie. Przyrzekli już zjazd swój wszyscy uczeni starożytnicy z Niemiec, Francyi, Anglii, Włoch, Węgier i Rossyi. Przy téj sposobności zachęcam Sza-

5 Księgarnia założona w 1862 r. przez Franciszka Grzybowskiego, mieściła się w Pałacu Zbaraskich w Krakowie (por. G. Schmager, Franciszek Grzybowski, [w:] Stownik pracowników książki polskiej, red. I. Treichel, Warszawa-Lódź 1972, s. 304), dziś Rynek Główny 20. Była tam także wypożyczalnia i skład nut. Właściciel zajmował się również działalnością wydawniczą. W latach 1869-1872 księgarnię tę prowadził Franciszek Trzecieski, a następnie do 1877 Adolf Dygasiński. Wszystkie te księgarnie zbankrutowały.

6 Jeżewo Stare (Stare Jeżewo) - wieś w gminie Tykocin, powiat białostocki, województwo podlaskie. Tu znajdował się majątek kupiony przez ojca Zygmunta Glogera, w którym rodzina Glogerów mieszkała przez kilkadziesiąt lat. Do Jeżewa przyjeżdżało wiele ówczesnych znakomitości świata nauki, literatury, sztuki, jak na przykład Julian Bartoszewicz, Henryk Sienkiewicz, Narcyza Żmichowska, Elwiro Andriolli. Do dzisiaj nie zachowały się budynki dworskie, pozostały jedynie ruiny browaru i rządcówki.

7 Chodzi o tekst Izydora Kopernickiego O kościach i czaszkach ludzkich z kurhanów w Radziminie na Wolyniu (z 1 tablicą), „Zbiór Wiadomości do Antropologii Krajowej” 1877, t. 1, s. 48-54. 
nownego Pana w najwyższym stopniu, do wzięcia udziału w téj wielkiej dla nas uroczystości - chodzi tu o nasz honor! A na nieszczęście ludzi mamy bardzo mało, doniosłość zaś zjazdu będzie wielka - trzeba więc skupić wszystkie lepsze siły umysłowe pracujące w tym lub przybliżonym kierunku. Mamy dwa lata czasu, które z energią woli spożytkować winniśmy. Nie chodzi tu o obszerne rozprawy, bo i na ostatnim kongresie w Peszcie ${ }^{8}$, tylko po 20 minut dla każdego mówcy naznaczono. Dobrze byłoby mieć i koniecznie potrzeba, obszerne sprawozdania, które wydane zostały przez każdy z sześciu archeologicznych kongresów, a one nauczą więcéj niż wszystkie inne dzieła razem wzięte, bo obejmują całą archeologię i ostatni jej wyraz. Żałuję, że nie posiadam wszystkich dzieł kongresowych, sam korzystając z pożyczanych, bo przesłałbym je Szanownemu Panu. Narzucam się - ale w imie nauki i prowincyi, która jeżeli Szan. Pan. nie stanie, nikogo mieć nie będzie godnego. Ja zamierzam na przyszłym zjeździe dać treściwy, lecz ciekawy, obraz użytku krzemienia między Odrą i Dnieprem. Należałoby także zbierać wszelkie wykopaliska dla pomnożenia wystawy kongresowej, żeby godnie przedstawić przeszłość przedhistoryczną.

Poradnik ${ }^{9}$ Szan. Pana, dla zbieraczów rzeczy ludowych mam, nawet rozsyłałem go w różne strony. Za to innych Jego prac nie posiadam i byłbym za upominek serdecznie obowiązany. Pani Dobrodziejce rączki całuję i z wysokim szacunkiem i poważaniem dla Obojga Szanownych Państwa pozostaje

\section{Zygmunt Gloger}

\section{Jeżewo, d. 30 Stycz. 1888 r.}

Pracę moją pragnąłbym posiadać w jednej broszurce, żeby na podarek przyzwoity służyć mogła. Aby zaś wszystkich czcionek w złożeniu nie zatrzymywać do wyjścia drugiej połowy, co dla drukarni może być uciążliwem, to sądzę, iż pierwsze arkusze można zaraz po odbiciu pewnej liczby, którą postanowicie, rozebrać, zostawiwszy tylko stronice końcowe, które mogą być do związania z drugą połową potrzebne.

Z wdzięcznością i przyjaźnią

\section{Gloger}

8 Międzynarodowy Kongres Antropologii i Archeologii Przedhistorycznej odbył się w Peszcie w $1876 \mathrm{r}$.

9 J. Karłowicz, Poradnik dla zbierajacych rzeczy ludowe, Warszawa 1871. 


\section{Jeżewo d. 3 Kwietnia, 1888 r. ${ }^{10}$}

Plan cerkiewki Kołożańskiej11 widocznie zaginąć musiał u Żupańskiego ${ }^{12}$, który chciał wydać ozdobnie moją podróż po Niemnie i miał rękopis ze wszystkiémi rysunkami u siebie, ale że nie dotrzymał warunków (które były te: że ma wydać w ciągu roku od umowy i drzeworyty zrobić w Warszawie), więc odsyłając z niechęcią, zwrócił mi wszystko w nieporządku, nieopieczętowane, przez osobę obcą. Ja rękopisu przed oddaniem do Wisły nie czytałem i ztąd zapomniałem, że należało wykreślić w nim wzmiankę o planie, którego brakowało. Teraz sądzę, że gdy nie podaliśmy go we właściwem miejscu, to w drugim tomie poruszać téj kwestyi już nie należy. Przy téj sposobności załączam do Szanownego pana prośbę notabene tylko w razie, jeżeli jest możliwą do urzeczywistnienia. Chodzi mi o posiadanie zużytych w podróży niemnowéj drzeworytów, które zapewne dla nikogo wartości żadnej przedstawić nie będą, a mnie mogą się przydać za lat kilkanaście, tak jak np. Wiśle przydały się drzeworyty krzemieni z wydawanych ongi Wiadomości Archeologicznych.

10 LVIA, k.24-25.

11 Cerkiew kołożańska to cerkiew świętych Borysa i Gleba, najstarsza cerkiew prawosławna w Grodnie. Została zbudowana na Kołoży przy ujściu rzeki Horodniczanki do Niemna. Pierwsze wzmianki o tym obiekcie pochodzą z XII wieku (Cerkiew kołożańska).

„Wieczorem było wszystko ukończone, z wyjątkiem szkiców ruin starożytnej cerkiewki na Kołoży” (Z. Gloger, Podróż Niemnem, „Wisła” 1888, t. 2, z. 1, s. 33). „Publikowanych dokładnych widoków Kołoży niemamy wcale; jeden tylko przedstawiający cerkiew w oddaleniu, przed jej upadkiem, znajduje się w rzadkiej Tece Michała Kuleszy (wydanej w Paryżu), inny u Wilczyńskiego. Muzeum archeologiczne wileńskie posiadało szczegółowy rysunek, ścian obalonych, który także znajduje się u professora Podczaszyńskiego. Tutaj przedstawiam widok trzech ścian istniejących, odrysowany przezemnie, tudzież plan cerkwi, zdjęty przed katastrofą, a udzielony mi uprzejmie przez pana Pawła Bol. Podczaszyńskiego" (Z. Gloger, Podróż Niemnem, dz. cyt., s. 36). Do tekstu dołączono zdjęcie: zwaliska cerkwi na Kołoży pod Grodnem (s. 37).

12 Jan Konstanty Żupański (ok. 1804-1883) - księgarz i wydawca, działacz oświatowy, publicysta. Prowadził księgarnię nakładową i wypożyczalnię książek w Poznaniu. Wydał około 600 tytułów, w tym dzieła Joachima Lelewala, Maurycego Mochnackiego oraz serię „Pamiętniki z Osiemnastego Wieku" (t. 1-15, 1860-1875). Był jednym z inicjatorów powołania Poznańskiego Towarzystwa Przyjaciół Nauk (por. S. Dippel, O księgarzach, którzy przeminęli, WarszawaWrocław 1976; Nowa encyklopedia powszechna PWN, red. B. Petrozolin-Skowrońska, t. 6: S-Z, Warszawa 1996, s. 1087; Wielkopolski stownik biograficzny, red. A. Gąsiorowski, J. Topolski, Warszawa 1983). 


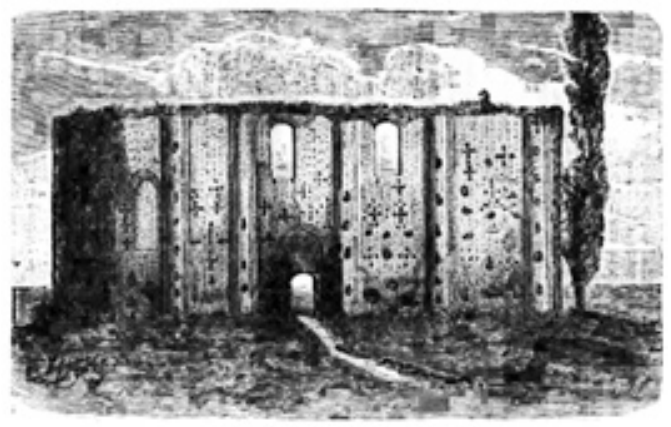

Cerkiew kołożańska w Grodnie.

Zdjęcie zamieszczone w „Wiśle”, w tekście Z. Glogera Podróż Niemnem

P. Federowski ${ }^{13}$ stanowczo przyjąć posady wiadoméj ${ }^{14}$ teraz nie może, ale czy doniósł o tem panu Kamieńskiemu, tego nie wiem, bo telegrafował tylko o tem do mnie i może liczył na pewno, że zobaczę się p. Kamieńskim. Ja zaś otrzymawszy depeszę ową prawie na wyjezdnem z Warszawy nie mogłem się już porozumieć osobiście z p. Kamińskim i liczyłem na to, że p. F. pozostając w korespondencyi bezpośredniej z p. K. zawiadomić go oddzielnie nie omieszka jako ofiarodawcę owego miejsca. Że się tak stało, wielka szkoda dla instytucyi etnograficznéj i sam Federowski żałować tego potem będzie i pewnie po jakim roku, gdy się przekona że gospodarstwo nie jest jego powołaniem, zechce naprawić swój błąd, jeżeli to będzie możliwem, o czém wątpić należy.

13 Michał Federowski (1853-1923) - samouk, badacz folkloru białoruskiego, autor kilkutomowej pracy Lud białoruski na Rusi Litewskiej. Materiały do etnografii stowiańskiej. Współpracował z Oskarem Kolbergiem, Janem Karłowiczem. W latach 1875-1877 pod kierunkiem Z. Glogera prowadził badania na Kielecczyźnie, czego rezultatem była dwutomowa monografia Lud z okolic Żarek, Siewierza i Pilicy, Warszawa 1888-1889 (por. M. Czurak, Michał Federowski (1853-1923), Etnograf i folklorysta amator, badacz białoruskiej kultury ludowej, [w:] Etnografowie i ludoznawcy polscy. Sylwetki, szkice biograficzne. Tom III, red. E. Fryś-Pietraszkowa, A. Spiss, Wrocław-Kraków 2007).

14 Być może chodzi tu o objęcie posady w dziale zbiorów etnograficznych w Ogrodzie Zoologicznym, który zorganizowano w 1888 r. z inicjatywy Komitetu Organizacyjnego Muzeum Etnograficznego. W skład tego Komitetu wchodzili m.in. Jan Karłowicz i Jan Maurycy Kamiński (1844-1907) - prawnik, literat, pomysłodawca założenia Ogrodu Zoologicznego w Warszawie (por. C. Gajkowska, Jan Maurycy Kamiński, [w:] Internetowy Polski Stownik Biograficzny; Państwowe Muzeum Etnograficzne w Warszawie - stulecie dziatalności (1888-1988), red. J. K. Makulski, Warszawa 1988, s. 34). 
Załączając dla Szanownych Pań uprzejme ukłony - pozostaję z poważaniem dla całego domu - szczery przyjaciel i sługa szanownego Pana

\section{Gloger}

Załączam Szanownemu Panu Mecenasowi list, z prośbą o zwrot po przeczytaniu

\section{Wierny sługa J. Karłowicz}

\section{Jeżewo d. 18 Lipca 1888 r. $^{15}$}

Szanowny Panie!

Powróciwszy z Litwy od mego teścia ${ }^{16}$, gdzie z rodziną przebywałem przez kilka tygodni, pozostaję obecnie $\mathrm{w}$ domu i przez żniwa nie mam zamiaru nigdzie dalej wyruszać. Wiadomość powyższą ośmielam się przesłać Szanownemu Panu na wypadek, gdybyście zechcieli drogi Panie Janie obietnicę zrobienia wycieczki na Podlasie, w tym jeszcze roku urzeczywistnić, co byłoby dla mnie i dla żony mojej prawdziwie miłą niespodzianką. Koleją Petersburską jedzie się z Warszawy do Łap ${ }^{17}$ (7. stacyj), najlepiej pociągiem dziennym, który wychodzi z Pragi około g. 10 rano a do Łap przybywa około 2ej w południe. Tam czekać będą moje konie z Jeżewa odległego od Łap wiorst 18. Inaczéj trzebaby u którego z panów Łapińskich (a jest ich około 200 dziedziców w 10 wioskach Łapy) za 8 złotych wózek, ale bardzo niewygodny i latem trudno czasem dostać koni, więc piszę o tem tylko na wypadek téj ostateczności, gdyby się Szanowny Pan spóźnił na umówiony pociąg lub w żaden sposób nie mógł w dniu przybycia wcześnie mnie zawiadomić. Pod wyrazem „wcześnie” rozumiem list wyprawiony z Warszawy przez Tykocin do Jeżewa na 5-6 dni przed wyjazdem (list idzie dni 3).

W miłej nadziei powitania Szanownego Pana w progu podlaskiej mojej pracowni - pozostaję z prawdziwym szacunkiem i przyjaźnią

Z Gloger

15

LVIA, k.26-27.

16 Teść Z. Glogera Aleksander Jelski (1834-1916) - etnograf, publicysta, pisarz historyczny, mieszkał w Zamościu w powiecie ihumeńskim (obecnie Замосце w obwodzie mińskim na Białorusi). Założył tam bibliotekę i muzeum starożytności (por. W. Bieńkowski, Aleksander Jelski (1834-1916), [w:] Internetowy Polski Stownik Biograficzny).

17 Łapy - miasto w powiecie białostockim. Obecnie podróż pociągiem z Warszawy do Łap zajmuje dwie godziny. 
Zapewne wyszedł już II tom Wisty ${ }^{18}$ i odbitki Niemna.

\section{Jeżewo d. 20 Sierpnia 1888 r. ${ }^{19}$}

Szanowny Panie!

Artykuł pana Wejtki ${ }^{20}$ robi ze wszech miar sympatyczne wrażenie i daje nadzieję, że z tego początkującego archeologa, jeżeli będzie pracował i na początek więcej czytał, niż kopał, a w dodatku znajdzie sposobność poznania wytrawniejszych archeologów i ich zbiorów niż p. Wolter, to może być bardzo pożądanym i pożytecznym pracownikiem dla litewskiej przeszłości.

Sam jednak artykuł nie podaje nam rzeczy bardzo ciekawych lub nieznanych, które podług mnie skłaniałyby „Wisłę” do przekroczenia zamierzonego programu i wzięcia się do téj pracy pana Wejtki do archeologii. Z tem wszystkiem opis kurhanu oławskiego bezwarunkowo zasługuje na wydrukowanie i radziłbym posłać go do Krakowa Kopernickiemu ${ }^{21}$, a panu W. wytłumaczyć, że to bynajmniej nie narazi jego wojskowego stanowiska, że Akad. Nauk krak. wydrukuje jego pracę, naprzód bowiem nikt w Rosyi artykułu jego czytać ani wiedzieć o nim nie będzie, a powtóre archeologia należy do nauk błahonadiożnych nawet w Rossyi i hr. Uwarow ${ }^{22}$ i Spasowicz ${ }^{23}$ byli członkami Akademii krak. przez Rząd zatwierdzonymi.

18 W tomie drugim „Wisły” (1888) ukazały się dwa teksty Z. Glogera: Podróż Niemnem i Święta Bożego Narodzenia w Radłowie. W tym numerze zamieszczono także notkę, autorstwa J. Karłowicza, o wydaniu książki Z. Glogera Skarbczyk. Zwyczaje doroczne.

19 LVIA, k.28-29.

20 Wacław Wejtko (1861-1940) - archiwista i kolekcjoner starożytności, pracownik Archiwum Państwowego w Wilnie. Sporządził kartotekę prawie 6 tysięcy pomników osób zasłużonych dla miasta, pochowanych na Rossie i cmentarzu Bernardyńskim do 1940 roku (por. także A. S. Czyż, B. Gutowski, Cmentarz na Rossie w Wilnie: niezachowane pomniki na podstawie kartotek Wacława Wejtki, Lucjana Uziębly i Aleksandra Śnieżki, Warszawa 2017).

21 Izydor Kopernicki (1825-1891) - antropolog, lekarz. Był sekretarzem Komisji Antropologicznej Polskiej Akademii Umiejętności w Krakowie, redaktorem „Zbioru Wiadomości do Antropologii Krajowej” (1877-1891) i „Przeglądu Akademickiego” (1881-1889). Wraz z Józefem Majerem należał do twórców krakowskiej szkoły antropologicznej (por. S. Kieniewicz, P. Sikora, Izydor Kopernicki (1825-1891) [w:] Internetowy Polski Stownik Biograficzny).

22 Siergiej Siemionowicz Uwarow (Сергей Семёнович Уваров) (1786-1855) - minister oświaty w Imperium Rosyjskim (1833-1848).

23 Włodzimierz Spasowicz (1829-1906) - prawnik, publicysta, zagraniczny członek czynny Akademii Umiejętności w Krakowie (por. Rocznik Akademii Umiejętności 1898/9, Kraków 1899, s. 10), wydawca czasopisma „Ateneum” i słynnego tygodnika polskiego w Rosji „Kraj”, współzałożyciel Towarzystwa Naukowego Warszawskiego. 
Zresztą wszystko od zapatrywania się Szanownego Pana zależy i Wisła, jeżeli ma środki zapasowe na drzeworyty archeologiczne i pragnie wcielić tę naukę do swego programu, to cóżbym ja, archeolog, mógł mieć przeciw temu?

Za książkę o masazie [? D.R.] w imieniu matki mojej i własnem serdeczne przesyłamy podziękowanie i prawdziwą wdzięczność za ten cenny dowód pamięci na zawsze zachowamy.

Co do perjódycznego przeglądu po archeologii krajowéj i zagranicznéj, to będąc bardzo ścisłym i drobiazgowym w nauce, podjąć się tego nie mogę, dopóki mam na głowie browar, którego pozbyć się pragnę.

Załączając ukłony Szanownym Paniom - pozostaję Waszym szczerym przyjacielem i sługą

\section{Z. Gloger}

Artykuł pana Wejtki odsyłam jednocześnie. Odbitek jeszcze nie dostałem

\section{Jeżewo d. 5 Maja 1889 r. ${ }^{24}$}

Szanowny Panie Janie!

Otrzymałem na tych dniach list od p. Mich. Federowskiego z Kosina ${ }^{25}$ pod Wołkowyskiem zapraszający nadzwyczaj serdecznie nas obu do siebie na cały miesiąc! Tyle bowiem czasu, jak twierdzi, zajmą poszukiwania archeologiczne i etnograficzne w tamtéj okolicy. Co do mnie, to nie może być mowy o tak długim pobycie. A któżby ciągnął za mnie taczkę kłopotów gospodarsko-browarnych? Teraz obsiewam jarzyny, a w ostatnich dniach maja odwiozę żonę z Janką na 3 tygodnie do Zamościa, a później znowu po nich pojadę. Ale szanownego pana namawiałbym usilnie na wycieczkę do Jeżewa, a z Jeżewa razem do Kosina, gdzie ja dni kilka, a szan. pan mógłby dłużéj zabawić. Federowski jest człowiekiem nader gościnnym i ma dar zjednania sobie ludu, tak że na każde zawołanie otacza się całą czeredą młodych i starych śpiewaczek. Taka więc wycieczka przyniosłaby nieocenione skarby dla muzyki z okolic, w których nikt nigdy umiejętnie ani jednej melodyi nie zanotował. A i z mojej okolicy, choć mam uchwyconych kilkadziesiąt melodyj, ale z pewnością nie wszystkie. Czas podobnie przepędzony byłby dla szanownego pana odpoczynkiem nie-

24 LVIA, k. 30-31.

25 Kosin - majątek pod Wołkowyskiem, który dzierżawił w latach 1884-1894 M. Federowski. Obecnie Косіна w obwodzie grodzieńskim na Białorusi. 
zbędnym dla Jego zdrowia, tak pożądanego zarówno dla rodziny, jak i kraju, a jednocześnie spożytkowanym dla nauki. Mam nadzieję, że Szanowny pan przychyli się do prawdziwie przyjacielskiej rady mojej. Należałoby w takim razie porozumieć się tylko co do terminu przyjazdu do Jeżewa i wycieczki na Litwę, ułatwionéj teraz bardzo, bo Federowski mieszka o 6 wiorst od Wołkowyska, przez który idzie kolej Baranowicka, kędy jeździmy do rodziców mojej żony, tak że nawet myślę o skombinowaniu wycieczek litewskich w jedną podróż.

Załączając uprzejme ukłony dla Czcigodnych pań i - pozostając dla szanownego pana z serdeczną przyjaźnią i szacunkiem

\section{Zygmunt}

\section{Jeżewo d. 1 Sierpnia 1889 r. ${ }^{26}$}

Drogi Panie Janie!

Piszę do drogiego Pana w chwili wyjazdu z żoną i córką do Zamościa na 3 tygodnie lub miesiąc, a w bardzo przykrym nastroju z powodu, iż szczególny i nieprzewidywany zbieg okoliczności nie pozwala mi być słownym w odesłaniu drugiéj połowy łaskawie pożyczonych mi pieniędzy. Oto dzierżawca mój wyjechał przed tygodniem na 2 dni do sędziwych moich rodziców i po odbiór należnych mu funduszów. Po powrocie miał zakończyć zemną tegoroczny nasz rachunek, a ja ze źródła tego miałem dopełnić natychmiastową wysyłkę dla Szanownego pana do Grodziska ${ }^{27}$. Tymczasem nagła choroba jego matki niepozwoliła powrócić mu do dzisiaj, a ja wyjazdu mego na Litwę w żaden sposób odłożyć nie mogę, bo w Mińsku czekają na nas rodzice żony i konie wysłane o mil 7. Dokładnie oznaczyć, kiedy powróci mój dzierżawca do domu nie mogę, a zresztą tylko osobiście mógłbym załatwić z nim interes pieniężny z mnóstwa cyfr i pozycyj złożony. Nawiasowo nadmieniam tylko, iż trafiłem na człowieka bardzo sumiennego i znakomicie uzdolnionego rolnika, który gospodarstwo jeżewskie nie tylko nie opuści, ale na wysokim postawić może stopniu, czego sobie bardzo ze względu na przyszłość mego Stasia ${ }^{28}$ życzę. Jest dziecko

26 LVIA, k. 31-33.

27 W 1889 r. J. Karłowicz spędzał wakacje w Grodzisku pod Warszawą; E. Majewski, Zarys życia, [w:] Życie i praca Jana Karlowicza (1836-1903), Warszawa 1904, s. 29.

28 Chodzi o jedynego syna Z. Glogera Stanisława (zmarł w 1953 r. w Szczytnie, por. L. Gloger, J. Ławski, ,...od najmłodszych lat pamiętam książki jego autorstwa $w$ domowej biblioteczce..." Rozmowa z Liliana Gloger, „Bibliotekarz Podlaski” 2017, nr 1, s. 143). 
obecnie o tyle lepiej, że na kilka tygodni opuścić go już możemy poruczając opiece babci. Raz jeszcze najmocniej przepraszając za niemożliwość spełnienia danego przezemnie przyrzeczenia i zwłokę, która w odesłaniu téj reszty nastąpić musi - ściskam zacną dłoń Waszą najserdeczniej wierny przyjaciel i sługa

\section{Zygmunt}

Panie moje przesyłają drogiemu Panu ukłony i razem ze mną życzenia szczęśliwej podróży i powrotu.

Cały czas mego pobytu w mińszczyźnie zamierzam poświęcić na wycieczki naukowe.

\section{Jeżewo d. 27 Marca 1890 29}

Szanowny Panie Janie!

Wyczytałem w „Kraju” wiadomość o polemice p. de Fleury ${ }^{30}$ z Szanownym panem w kwestyi Wandy i Meluzyny, do której to polemiki p. de F. najniepotrzebniej wmięszał i moje nazwisko. Zapytywał on mnie listownie o zdanie co do mogiły Wandy. Odpisałem mu (dosłownie nie pamiętam, bo to już dosyć dawno), że kopiec uważam bezwarunkowo za mogiłę. Wieś przy nim położona już w średnich wiekach nosiła nazwę „Mogiły”. W téj saméj wielkości usypiskach na Ukrainie (np. Perepiata i Perepiotychy ${ }^{31}$ ) i innych, znaleziono bogate grobowce starożytnych panujących lub wodzów. Kopiec jest téj wielkości iż go sypać musiał cały lud okoliczny i to przez rok jeden. Takiż prawie kościuszkowski budowano lat kilkanaście rękami tłumów. W kraju górzystym jak Krakowskie, nie mogło chodzić o pozyskanie wyniosłości pod jakiś np. ołtarz ofiarny, bo na to miano daleko wyższe góry naturalne jakich niema na Ukrainie. Kronikarze twierdzą, że to jest mogiła Wandy i ja jestem tego samego zdania, ale rzecz zupełnie odrębna czy ta jakaś pochowana w olbrzymim grobowcu

30 J. Karłowicz wydał tekst Piękna Meluzyna i królewna Wanda, opublikowany w czasopiśmie w „Ateneum” 1876 t. II, 457-498; III, 137-167. Na temat tej legendy w 1890 r. ukazała się 11-stronicowa broszura autorstwa L. de Fleury'ego La reine Vanda ou une pretendue Melusine polonaise (por. H. Łopaciński, Jan Karłowicz. Ludoznawstwo, mitologja, kultura pierwotna, [w:] Życie i prace Jana Karlowicza (1836-1903), Warszawa 1904, s. 257). Wspomnianą krytykę wydrukowano w czasopiśmie „Kraj”.

31 Dwa kurhany - Перепят і Перепятиха - były wzmiankowane w letopisach już w XII wieku; znajdują się na obrzeżach wsi Марьяновка w obwodzie kijowskim. 
Wanda zajmowała na świecie takie samo stanowisko jak Wanda opisywana przez kronikarzy. W obronę prawdziwości podań kronikarskich ani myślę wdawać się. Byłoby śmiesznem dowodzić że szczegóły podane przez kronikarzy z życia Wandy są faktami historycznemi. W mogile może leżeć kobieta która się nigdy nie topiła ani z Rydygierem nie miała żadnego zajścia. Takich wydarzeń historycznych nie mogłem dotykać ani bronić, uznając ich mytyczny w wysokim stopniu charakter. Pisałem tylko o kopcu, który niewątpliwie jest grobowcem jakiejś historycznéj postaci. Z panem de Fleury ${ }^{32}$ widuję się bardzo rzadko i polemiki jego nie czytałem. List mój w żaden sposób nie mógł mu służyć za argument do dowiedzenia autentyczności podań historycznych, a nierad jestem, gdy pismo moje występuje w roli świadka.

Mam zebrany obfity materjał i ciekawy etnograficzno-statystyczny o drobnéj szlachcie podlaskiej od początku osiedlenia jej w tych stronach aż do chwili obecnej. Rzecz to do Wisły zaobszerna bo na mały tomik druku zakrawa. O takiéj że szlachcie mazowieckiej pisał Smoleński ${ }^{33}$ i Junosza ${ }^{34}$ ale podlaskiej nikt nie dotknął i nie posiada takich jak ja obszernych, a wyczerpujących wiadomości. Gdybym wiedział, że praca wydaną będzie, to wziąłbym się do uporządkowania rękopisu.

Załączając życzenia wesołych świąt i ukłony dla szanownych pań - pozostaję z serdeczną dla drogiego Pana przyjaźnią i szacunkiem.

sługa wasz

\section{Z Gloger.}

P.S. W razie polemiki z p. de F. raczcie nie robić użytku z listu niniejszego.

32 Ludwik de Fleury (1828-1909) - pochodzenia francuskiego prawnik, ziemianin, właściciel majątku Kępa Giełczyńska nad Biebrzą (majątek nie istnieje, teren ten obecnie należy do Biebrzańskiego Parku Narodowego), hodowca koni, z zamiłowania archeolog amator, a także malarz, fotograf, kolekcjoner sztuki, członek Francuskiego Stowarzyszenia Rozwoju Nauk (Marczak - z dalszą literaturą).

Gloger w tekście $W$ dolinie Biebrzy wspomina o tym ziemianinie, który był uczestnikiem wspólnej wyprawy po Biebrzy: „Hrabia de Fleury z prawdziwym zamiłowaniem zajął się wyszukiwaniem krzemiennych przedmiotów na swym dziedzińcu, w ogrodzie i na poblizkiej drodze i utworzył małe muzeum, w którym nie brakuje żadnego kształtu i typu narzędzi krzemiennych i kamiennych” (Z. Gloger, W dolinie Biebrzy, „Wisła” 1892, t. 6, z. 1, s. 18).

33 W. Smoleński, Szkice z dziejów szlachty mazowieckiej, Kraków 1908.

34 J. K. Szaniawski, Wybór pism. Panowie bracia. Szkic z życia szlachty zagonowej, t. 3, Warszawa 1891. 


\section{Jeżewo d. 23 Kwietnia 1890 r. ${ }^{35}$}

Szanowny Panie Janie!

$\mathrm{Na}$ otrzymany przed chwilą list Wasz odpisuję natychmiast w nadziei, że odpowiedź moja zastanie Was jeszcze w Warszawie. Współczujemy bardzo cierpieniu Szanownego pana z powodu kokluszu, a matka moja, która na wiele chorób posiada skuteczne domowe lekarstwa, poleciła mi zakomunikować, że raz sama siebie wyleczyła z kokluszu pijąc zaparzone jak herbatę „bagno”36, a mianowicie 3 do 4 listków téj rośliny (podobnéj do rozmarynu) trochę wysuszonych i potem wrzuconych do czajnika lub szklanki z ukropem.

Żałuję bardzo, że nie poznałem Brüchnera ${ }^{37}$, o odkryciu zabytku mowy polskiej czytałem w Kraju ${ }^{38}$. W Petersburgu musi być jeszcze potężna kopalnia rzeczy naszych. Bibljoteka Załuskich była w połowie zeszłego wieku największą w Europie. Dla professorów Zawilińskiego ${ }^{39}$ i Rozmuskiego ${ }^{40}$ wątpię, czy co wyszukam. Bo chociaż papierów po Branickich mam moc, ale ekonomiczne dotyczą tylko dóbr podlaskich, a nie tyczyńskich w Galicyi i nazwiska, o które chodzi, nie przypominam sobie.

35 LVIA, k.36-37.

36 Bagno zwyczajne (Ledum palustre L.) to gatunek rośliny dziko rosnącej, nazywanej też rozmaryn leśny, bagiennik, świńskie bagno, toza, bahun. Napar z bagna był stosowany w lecznictwie ludowym jako środek na kaszel i gruźlicę (A. Fiszer, Rośliny w wierzeniach i zwyczajach ludowych. Stownik Adama Fischera, oprac. M. Kujawska, Ł. Łuczaj, J. Sosnowska, P. Klepacki, Wrocław 2016, s. 339-340).

37 Chodzi o Aleksandra Brücknera (1856-1939), językoznawcę, m.in. autora Stownika etymologicznego języka polskiego (1926-1927), Dziejów języka polskiego (1906), Mitologii stowiańskiej (1918), Encyklopedii staropolskiej (1937-1939).

38 „Kraj” - polski tygodnik społeczno-polityczny wydawany w latach 1882-1909 w Petersburgu. Jego założycielami i redaktorami byli Włodzimierz Spasowicz i Erazm Plitz (por. A. Janicka, Stownik czasopism, [w:] Zygmunt Gloger, Pisma rozproszone, Tom III: 1890-1910, red. J. Ławski, J. Leończuk, Białystok 2016, s. 99).

39 Roman Zawiliński (1855-1932) - językoznawca, pedagog, etnograf. Przez dwie kadencje pełnił funkcję sekretarza działu etnograficznego Komisji Antropologicznej Akademii Umiejętności w Krakowie. Był założycielem i wieloletnim redaktorem miesięcznika językoznawczego „Poradnik Językowy” oraz w latach 1913-1916 redaktorem naczelnym czasopisma „Język Polski”. Jest m.in. autorem książki Wskazówki do zbierania właściwości ludowych (1886) i słownika Dobór wyrazów. Stownik wyrazów bliskoznacznych i jednoznacznych do praktycznego użytku (1926-1928), por. I. Stąpor, Roman Zawiliński (1855-1932).

40 Chyba chodzi o Czesława Rozumskiego (1849-1894) - nauczyciela III Gimnazjum w Krakowie. 
Ma być u mnie w tych dniach p. Jan Zacharjasiewicz ${ }^{41}$, przynajmniej Pług ${ }^{42}$ pisał do mnie, że towarzysz jego wybiera się napewno. Pan Z. w pierwszych dniach Maja zapewne powróci do Warszawy, więc przez niego chciałbym przesłać do Wisły koniec podróży po Bugu, dawno już gotowy, ale prawie trzy razy dłuższy od początku, pomimo treściwości mego stylu. Razem praca ta zajmie około 40 stronic. Honorarium raczcie drogi panie Janie zachować u siebie na rzecz regulacyi naszego rachuneczku. Gdyby Zacharjasiewicz nie przyjechał, rękopis odeszlę chyba pocztą.

Paniom szanownym ukłony razem z żoną moją załączam i d[r]ogiego pana ściskam serdecznie życząc rychłego zwycięstwa nad kokluszem.

Wasz Zygmunt.

\section{Warszawa d. 23 Sierpnia $91 r^{43}$}

Szanowny Panie Janie!

Wyjechawszy z domu w d. 17ym Lipca i zawiózłszy żonę z dziećmi na 2 miesiące do rodziców, spędziłem cały miesiąc na bardzo interesujących wycieczkach pomiędzy Niemnem i Dnieprem w gub. Mińskiej i Mohilewskiej. Wstąpiwszy na chwilę do domu, w drodze z Litwy do Warszawy, zastałem tam oczekujący na mnie od trzech tygodni list Wasz ze Szląska w d. 29 lipca wysłany. Najmocniej przeto przepraszam za zwłokę w odpowiedzi, z nieobecności w domu wynikłą, ale matka moja nie otwierając nigdy listów do mnie adresowanych, nie ufając pocztom zaniemeńskim i nie wiedząc na pewno, gdzie mnie szukać, składa je tylko do czasu mego powrotu. Przybywszy do Warszawy korzystam z pierwszéj wolnéj chwili, aby te słowa skreślić, do których dołączam rubli 40 a conto należnych jeszcze odemnie czcigodnemu Panu Janowi rs stu czterdziestu. Pozostaje więc jeszcze rubli sto oraz procent. Ostatnie 2 lata z powodu niefunkcjonowania mojej fabryki piwnéj i różnych banifikacyjj4

41 Jan Chryzostom Zacharjasiewicz (1823-1906) - pisarz i dziennikarz (por. E. Lubowski, Jan Zacharyasiewicz, „Kłosy” 1875, nr 517, s. 327-330). Jest uznawany za jednego z najpłodniejszych pisarzy nurtu pozytywistycznego w literaturze polskiej.

42 Antoni Pietkiewicz, ps. Adam Pług (1823-1903) - pisarz, biograf, publicysta, redaktor Wielkiej encyklopedii powszechnej ilustrowanej.

43 LVIA, k.38-39.

44 Bonifikacja - zmniejszenie ustalonej ceny usługi lub towaru; bonifikata. 
dla dzierżawcy folwarku umie [sic!] wyjątkowo niepomyślne i ciężkie. Był to jednak stan przejściowy. Bonifikacje rok bieżący pokryje, a browar wydzierżawiam od nadchodzącéj jesieni bardzo solidnemu ziomkowi za rs 2000 rocznie.

Ponieważ szanowny Pan wskazuje swój adres na cały sierpień, a list niniejszy z pieniędzmi powinien być wysłany przez pocztę w dniu jutrzejszym, t.j. 24ym b.m., zatém niewątpię, że przed 1ym Września zastanie Go jeszcze na Szląsku. Wiadomość o powrocie drogiego pana do zupełnego zdrowia była nader miłą dla mnie i matki mojej, która poleca mi wyrazić w każdym liście do Was sympatyczną jej pamięć. Ja siedzę tu nad skończeniem potężnéj roboty, którą p. Nos opóźnił. Dziś cała noc tak straszna - burza i ulewa w Warszawie panuje (piszę przy ciągłych piorunach), że przypomina to jakieś czasy diluvialne.

Nie wiem, gdzie czcigodna rodzina Wasza się znajduje, ale w każdym razie proszę oświadczyć Paniom moje ukłony i przyjąć dla siebie serdeczny uścisk wiernego przyjaciela

\section{Zygmunt}

Do 25 Września bawię w Warszawie (Nowy Świat nr. 41 u Pietkiewicza)

\section{Warszawa Chmielna 5917 listop 1901 r. $^{45}$}

\section{Czcigodny Panie Janie!}

Podług dawnych zwyczajów weselnych do ślubu przybywają wieczorem, a napitek i długa droga do kościoła, podczas któréj śpiew i muzyka ani na chwilę nie milknie, nadają się do improwizacyi:

Pomału swatkowie, pomału

A z téj wysokiej goreńki

Niech ja się napatrzę

Zielonéj dąbroweńki

Oj kołem, kołem, kołem

Słoneczko chodzi (t.j. już zachodzi)

Nasza dziewczyna nasza nadobna

Do ślubu odchodzi. 
Słoneczko się śćmiło, ziemia się podała

Jak nasza (np. Marysia) do ślubu jechała.

Zabłądziła nasza pani młoda wśród boru

Nie wiedziała którędy iść miała do dworu.

Stój, nie gibaj się kalinowy moście

Kędy będą jechać marysine goście.

Zabierajcie się moi swatkowie.

Już nam czas.

Daleka droga, głęboka woda,

Ciemny las.

Już od ślubu jedziemy

Świec nie potrzebujemy

Bo zaświecim i sami

Złotemi pierścienicami

Drogiemi kamieńcami.

Jakem żenił się młody,

Miesiąc pełnił się wtedy

Jasne zorze gorzały

Gwiazdy niebo zasiały.

Z tej ostatniej śpiewki należy sądzić, że pełnia miesiąca uważana była W astrologii średniowiecznej za najlepszą porę do zawierania związków małżeńskich, których pierwszym warunkiem szczęścia była płodność, czyli pełnia macierzyńska. Wierzono, że wszystko co rosło wraz rosnącym młodym miesiącem, rosło pod dobrym znakiem, szczęśliwie. Więc też i dziś jeszcze starzy chłopi strzygą włosy na nowiu, żeby odrastały, a nie wypadały.

Mojem zdaniem piosnka:

„A pod miesiąc, moja Maryś, pod miesiąc.

Jużci ciebie zwiąże ksiądz"

jest przeżytkiem astrologicznym, którego sam lud prawdopodobnie już 
nie rozumie, ale śpiewa, gdy orszakowi weselnemu miesiąc na niebie zaświeci.

Nie mam tu Kłosów, ale domyślam się że piosnka musi być wzięta z „notatek świętokrzyskich" Edw. Chłopickiego ${ }^{46}$ które w powyższym tomie drukował.

Za starania o naukę muzyki dla chłopca z Królikarni serdeczne „bógzapłać".

Zachrypłem i nigdzie nie wychodzę, ale za tydzień pojadę do Krakowa. Może co załatwić? Stary przyjaciel i sługa

ZGloger.

\section{Warsz. d. 15 kwiet. 1902 r. ${ }^{47}$}

Szanowny Panie Janie,

Odsyłam z serdeczną podzięką pożyczony zeszyt Encykl. i uprzejmie proszę o pożyczenie mi na dwa dni kilka dziełka Muczkowskiego: Łacina w Polsce ${ }^{48}$.

Wdzięczny i wierny przyjaciel

\section{Gloger}

\section{Warsz. d. 17 kwiet. 902 [sic! ${ }^{49}$}

Szanowny Panie Janie!

Mecherzyńskiego ${ }^{50}$ odsyłam z serdecznem podziękowaniem i uprzejmie proszę o pożyczenie zeszytu Wielkiej Enc. Ilustr. z artykułem Grabowski Ambroży.

Wierny sługa

\section{Gloger}

46 Edward Chłopicki (1826 lub 1830-1894) - pisarz, podróżnik, etnograf. Owocem jego podróży po Litwie i Inflantach są Notatki z różnoczasowych podróży po kraju (Inflanty, Żmudź, Litwa, Pobereże) (zob. W. Jarmolik, Edward Chtopicki, amator rodzimych wędrówek, „Kurier Poranny", 2015, 11 listopada). Wydał także Od Stuczy do Bohu: kartki z podróży.

47 LVIA, k.42.

48 Chodzi zapewne o pracę Józefa Muczkowskiego, Pierwsze zasady języka łacińskiego, Kraków 1842.

49 LVIA, k.43.

50 Nie wiadomo, o jakiej pozycji autorstwa Karola Mecherzyńskiego (1800-1881) pisze Gloger. Być może chodzi o Historyę języka tacińskiego w Polsce, Kraków 1833. 


\section{Warszawa d. 29 maja, $1902 \mathbf{r}^{51}$}

Czcigodny Panie Janie!

Czytając niniejszą gryzmołę pomyślicie sobie: „Daj kurze grzędę, jeszcze wyżej będę!". Alić dla tego nazwano przysłowia mądrością narodów, że są źwierciadłem prawdy życiowéj. Tak i ja doświadczywszy dobroci Waszej w rzeczach Lachów i Nosówek ${ }^{52}$ udaję się z trzecią prośbą o Miesiące. Chodzi mi mianowicie o źródłosłów wyrazu miesiąc, choćby w kilku wierszach, ale przez Was skreślony i w dalszym ciągu tegoż artykuliku o wyjaśnienie kolejne naszych narodowych nazw miesięcy z zacytowaniem, jak są nazywane przez Ruś, Litwę i Czechów, a może jeszcze Łużyczan, jeżeli nazwy ich są pod ręką. Pod artykułem raczcie podpisać swe nazwisko lub litery. Literę $M$ zacznę drukować za jaki tydzień, więc za jakie 2 tygodnie przyjdzie kolej na „miesiąc”.

Najmocniej przepraszając i najserdeczniej dziękując za kradzież drogiego dla Was czasu, ale dla dobra publicznego spełnioną, pozostaję wiernym Waszym sługą

\section{Gloger.}

\section{Chmielna, 59}

[bez daty i początku listu] ${ }^{53}$

Lechici, którzy zostali rolnikami, nazwali się od pól polanami i polakami i tak też nazwali ich sąsiadowie zachodni. Lechici znowu, którzy nie siedzieli na polach, ale w lasach i nie mieli pól, ale jakieś zagony czy lechy w lasach, nie mogli się nazywać polanami, ale nazwę jakąś choćby dla samego przeciwstawienia polanom mieć musieli, a że wszyscy ich sąsiedzi od wschodu i południa nazywali lachami, więc przez samą analogję przypuszczać należy, że i oni sami siebie nazywali w zbliżony sposób. Gdy zaś sobie potrzebowali całe pola jak polanie, to zostali także polakami, bo nazwy te nie miały u nich nic wspólnego z narodowością, tylko ze sposobem życia, a tylko ustalone na obczyźnie już się zmieniać nie mogły, bo sąsiedzi nie badali zmian ich domowego życia, ale nazywali postaremu. Taka jest moja hypoteza od lat wielu, której jednak nie

51 LVIA, k.44.

52 O samogłoskach nosowych jako wybitnej właściwości języka polskiego napisał J. Karłowicz krótki artykuł do Encyklopedji staropolskiej Glogera (t. III, 264).

53 LVIA, k. $45-45 \mathrm{v}$. 
wygłaszałem, nie mając dostatecznych na jej poparcie dowodów językowych. Obecnie, gdy chciałbym w Enc. Starop. napisać cokolwiek pod wyrazami $L a-$ chy i Polanie ${ }^{54}$, radbym zacytować zdanie pana Jana Karłowicza jako znanego lingwisty. Chodzi mianowicie, w jakim związku mogą pozostawać do siebie wyrazy Lach, Lech, lecha, las.

\section{Bibliografia}

\section{Źródła archiwalne}

LVIA - Lietuvos valstybès istorijos archyvas, F 1135 Vilniaus mokslo bičiuliu draugija (Towarzystwo Przyjaciół Nauk w Wilnie), Ap 10 Kalbininko, etnografo, tautosakininko Jano Karlovičiaus asmeninio archyvo bylu apyrašas, Listy do Jana Karłowicza na litery G-I, j.a. 96.

\section{Literatura}

Bieńkowski W., Aleksander Jelski (1834-1916), [w:] Internetowy Polski Słownik Biograficzny, https://www.ipsb.nina.gov.pl/a/biografia/aleksander-jelski?print [dostęp: 1.02.2020].

Cerkiew kołożańska, Свята-Барыса-Глебская Каложская царква. Гісторыя царквы, http://kalozha.by/be/kalozha/gistoryya-tsarkvy [dostęp: 11.02.2020].

Czurak M., Michał Federowski (1853-1923), Etnograf i folklorysta amator, badacz białoruskiej kultury ludowej, [w:] Etnografowie i ludoznawcy polscy. Sylwetki, szkice biograficzne. Tom III, red. E. Fryś-Pietraszkowa, A. Spiss, Wrocław-Kraków 2007, s. 74-76.

Czyż A. S., Gutowski B., Cmentarz na Rossie w Wilnie: niezachowane pomniki na podstawie kartotek Wacława Wejtki, Lucjana Uziębły i Aleksandra Śnieżki, Warszawa 2017.

Dippel S., O księgarzach, którzy przeminęli, Warszawa-Wrocław 1976.

Fiszer A., Rośliny w wierzeniach i zwyczajach ludowych. Słownik Adama Fischera, oprac. M. Kujawska, Ł. Łuczaj, J. Sosnowska, P. Klepacki, Wrocław 2016.

54 Ostatecznie w Encyklopedii staropolskiej znalazło się tylko hasło Lachy (III 130-131). 
Gajkowska C., Jan Maurycy Kamiński, [w:] Internetowy Polski Słownik Biograficzny, https://www.ipsb.nina.gov.pl/a/biografia/jan-maurycy-kaminski [dostęp: 1.02.2020].

Gloger L., Ławski J., „...od najmłodszych lat pamiętam książki jego autorstwa w domowej biblioteczce..." Rozmowa z Lilianą Gloger, "Bibliotekarz Podlaski” 2017, nr 1, s. 141-148.

Gloger Z., Podróż Niemnem, „Wisła” 1888, t. 2, z. 1, s. 30-84.

Gloger Z., W dolinie Biebrzy, „Wisła” 1892, t. 6, z. 1, s. 1-18.

Janicka A., Słownik czasopism, [w:] Zygmunt Gloger, Pisma rozproszone, Tom III 1890-1910, red. J. Ławski, J. Leończuk, Białystok 2016, s. 95-104.

Jarmolik W., Edward Chłopicki, amator rodzimych wędrówek, „Kurier Poranny” 2015, 11 listopada, https://poranny.pl/edward-chlopicki-amator-rodzimych-wedrowek/ ar/9043981 [dostęp: 2.02.2020].

Karłowicz J., Poradnik dla zbierających rzeczy ludowe, Warszawa 1871.

Kieniewicz S., Sikora P., Izydor Kopernicki (1825-1891), [w:] Internetowy Polski Słownik Biograficzny, https://www.ipsb.nina.gov.pl/a/biografia/izydor-kopernicki [dostęp: 1.02.2020].

Kopernicki I., O kościach i czaszkach ludzkich z kurhanów w Radziminie na Wołyniu (z 1 tablicą), „Zbiór Wiadomości do Antropologii Krajowej” 1877, t. 1, S. $48-54$.

Łopaciński H., Jan Karłowicz. Ludoznawstwo, mitologja, kultura pierwotna, [w:] Życie i praca Jana Karłowicza (1836-1903), Warszawa 1904, s. 192-294.

Lubowski E., Jan Zacharyasiewicz, „Kłosy” 1875, nr 517, s. 327-330.

Majewski E., Zarys życia, [w: Życie i praca Jana Karłowicza (1836-1903), Warszawa 1904, s. 1-30.

Marczak J., Ludwik de Fleury (1828-1909), właściciel majątku Kępa n/Biebrzą, https://grajewiak.pl/index.php/biogramy/548-fleury-ludwik [dostęp: 1.03.2020].

Nowa encyklopedia powszechna PWN, red. B. Petrozolin-Skowrońska, t. 6: S-Z, Warszawa 1996.

Państwowe Muzeum Etnograficzne w Warszawie - stulecie działalności (1888-1988), red. J. K. Makulski, Warszawa 1988.

Piotrowska M., Budowanie wspólnoty w przestrzeni społecznej. Kilka uwag na marginesie "Obchodów weselnych" Glogera, [w:] Zygmunt Gloger 1845-1910: pisarz, myśliciel, uczony. Rewizje, red. J. Leończuk, J. Ławski, Ł. Zabielski, Białystok 2016, s. 95-106. 
Pruski [Zygmunt Gloger], Obchody weselne przez Pruskiego z pięcioma drzeworytami w tekście z dwoma tablicami nut i mapką w końcu dzieła dołączoną. Część pierwsza, Kraków 1869, s. 335-336.

Rocznik Akademii Umiejętności 1898/9, Kraków 1899.

Schmager G., Franciszek Grzybowski, [w:] Słownik pracowników książki polskiej, red. I. Treichel, Warszawa-Łódź 1972, s. 304.

Stąpor I., Roman Zawiliński (1855-1932), https://poradnik-jezykowy.uw.edu.pl/ page/editors [dostęp: 12.01.2020].

Wielkopolski słownik biograficzny, red. A. Gąsiorowski, J. Topolski, Warszawa 1983. 